\title{
Study on the Reform of Practical Teaching System of International
}

\section{Economics}

\author{
Ting Pan ${ }^{1}$ \\ ${ }^{1}$ Hubei Institute of Science and Technology, Xianning, Hubei, 4370002 \\ 346591653@163.com
}

KEYWORDS: International Economics; Practical Teaching System; Reform

\begin{abstract}
Practice teaching is an important part of the economics profession education and training system, to cultivate students' practical ability, innovative thinking and entrepreneurship awareness plays an important role. In the new century, with from elite education to mass education changes in higher education in China, with the ability to develop and enhance the quality of teaching practice focus more and more attention to social and universities. Through practice teaching system design framework, reform of practice teaching methods and teaching methods, constructing practice teaching platform in order to achieve cultivate practical ability and innovation ability of the first line of application-oriented talents.
\end{abstract}

\section{Introduction}

Hard practice refers to professional training programs in economics and clearly defined curriculum system, practice teaching each student must be completed on time and durability, mandatory, including non-professional military training and professional courses, professional internships. Refers to the practice of soft economic professional training programs and curriculum system is not clearly defined, the column is not in the economics of teaching content, students can voluntarily participate in one or more according to their own interests, does not have a mandatory practice teaching. Features such practice is that students have complete autonomy, students free theme, free combination, voluntary participation, only teachers with students' needs, to give some guidance. To encourage students to actively participate in the school's outstanding achievements given certain innovation credits, these credits, mainly in security research and student awards time as a reference.

Overall, the current economics "hard practice-based, soft practice supplemented by" practice teaching model has achieved some success in cultivating students' innovative spirit and practical ability, economic development and social needs but the angle point of view, there are still some urgent improvement.

(1) the practice of teaching system itself is not perfect. From a broad perspective, the practice of teaching system is a complete system by the target system, content system, management system and security system constructed in which the target system at the core position. Since the economics of practice teaching it is still largely seen as complementary theoretical teaching, a considerable part of the practical teaching, especially most of the simulations based on theoretical teaching a course and need to open, resulting in Practical teaching objectives are too narrow, the target system is not clear; practical teaching is more dispersed, overall content system is not strong; practice teaching 
management is not in place, the security system is not perfect. Manifested in the experimental course, less experimental class, small pilot projects and practice teaching management system, monitoring and evaluation of the measures in place on the system.

Bridging between practical teaching needs to be strengthened. The current practice of teaching economics prevalent in the overall concept is not strong, the lack of close ties between the practice teaching, practice teaching to "practice" and "practice", there is no purpose or purposes is not strong phenomenon. Experimental courses as an example, the experimental project set up primarily to enhance the students in this course some knowledge to understand and grasp, mostly verification and operability of the individual experiments, specifically for the study and follow-up courses offered scalability experiments small, and across the curriculum, a comprehensive multi-disciplinary design experiment is almost no. While taking into account the expertise of the timing of teaching content, according to the understanding of practice, production practice and graduation practice is carried out in sequence, from a practical point of view, and did not establish a solid link between the content of the three stages of practice, and this should be graduation thesis most closely linked, but also because the employment pressure, graduation practice mostly a formality and greatly reduced in quality, "hard practice" softening phenomenon is increasingly prominent. In addition, the practice of teaching inadequate attention to issues such as the status of the student body is also more prominent, these problems to some extent affected the effectiveness and quality of personnel training in economics teaching. Therefore, further reform and improve the economics of professional practice teaching system, teaching reform is an important economic task

\section{Several Problems in International Economics Reform}

In view of the theory and practice prevailing in Chinese universities, professor of international economics courses during divorced problem is relatively common, poor teaching effect reality, the practice of teaching system reform should pay attention to the following questions: 1. How shortened hours to ensure that the case of student mastery of knowledge and knowledge utilization level? 2. How in the limited teaching practice week of the latest international economics and the latest developments in the international economy into the teaching process? 3 . The manner in which they can better combine theory and practice, and promote active learning? 4. In the case of teachers teaching resources adequate to do to ensure the premise of how to design teaching content and degree of difficulty. Four, International Reform of Practice Teaching System of Practice Teaching System International Economics are not only reflected in the teaching mode reform, also requires teachers innovative teaching methods, the teaching content and international economic activities closely linked to encourage students the use of knowledge to explore realities of international economic issues.

\section{The Method of Practical Teaching Reform}

Laboratory construction laboratory is the main place student curriculum design and simulation practice. Economics pilot project includes basic experiments, comprehensive experiments, research and innovative experiments Basic experiments include demonstration experiments and experimental verification the future should focus on the development or the introduction of comprehensive experimental\% based integrated design experiments, design experiments and research \& innovative experiments, and actively create conditions for the implementation of practices set up a separate experiment teaching courses in economics. Economics preparations for the establishment of specialized laboratories, construction of professional practice teaching platform, the introduction of 
the experiment required software. Economics laboratory construction mainly includes two aspects. first, the course design platform, on the basis of the existing laboratory, designed the experimental data, the types of information required to prepare the experimental data tables, etc. plans to introduce China statistical Yearbook database, implementing the packet transaction, classroom teaching and curriculum design independently of each other, improve the ability of students to use economics relevant data analysis and economic development trends. experimental economics is the core of the project's experimental course, experimental economics is an important basis for the organization of teaching and assessment. Therefore, according to the progress of economic reform and focus on the development of technological disciplines, update teaching content and teaching methods and selection of economics, industrial economics, information economics metering, circulation economy science and other experimental projects. second, software construction, the introduction of formal econometric software, the use of this software, students can experiment regression analysis, simulation experiments were heteroscedasticity, autocorrelation sequence simulation, simulation multicollinearity, stochastic simulations explanatory variables, simultaneous equations simulation experiments. students' ability to conduct empirical analysis of economic issues will be raised.

Practice Base Construction. Practice Base is another platform economics practical teaching internship base construction ensures a long-term teaching internships and business contacts, internships and timely assessment of the situation for students to practice and feedback.

In order to improve the quality of teaching international economics, necessarily requires a research and teaching ability of teachers) and build international economics faculty need from the following aspects: 1 . strengthen discipline within the regular exchange of teachers and continuously improve the team spirit, in addition to actively communicate and exchange with other institutions related to teachers; 2. encourage teachers to other domestic and foreign institutions of higher learning and postgraduate training, and constantly improve the level of knowledge of teachers; 3. Encourages classroom teachers to conduct scientific research and the latest scientific research into teaching and realize the combination of research and teaching; 4. strengthen the training of teachers to enable them to skillfully use a variety of teaching methods, and effectively applied international economics Teaching practice.

The current international economic development a new phenomenon emerging, international economic theory is evolving and updated textbooks knowledge are somewhat lagging behind. Therefore, the combination of materials in teaching international economics in the process, we must pay close attention to international economic development trends, and promptly added new content and the introduction of new data, such as in teaching the theory of international trade, when to introduce new ideas and new theories of international trade currently occurring in the field; in teaching EU regional economic integration practice time, to introduce new data on the latest trends and development in the EU; talking about the exchange rate determination theory when, with the current depreciation of the dollar, the debt crisis and other realities linked, etc.).

Microeconomics! Macroeconomics and international economics and other higher mathematics foundation courses, international economics and international trade is! International Investment! Basic Course other professional courses international finance, etc.) in the economics profession teaching systems, international economics played an important bridge and link, so teaching practice should recognize the importance of international economics of this profession basic courses in teaching process for students has been revised over the course of knowledge to be recalled, the student has not repaired the knowledge of other professional courses should be introduced in order 
to reflect and to undertake the transition between disciplines, and continue to help students to cognitive entire economics of knowledge.

\section{Conclusion}

As one pair of mathematical thinking demanding course, how to deal with theoretical models and practical relationship between economic development is a very important issue) Therefore, in the teaching process of international economics, instructors should be based on the student's different levels and professional directions and hours arrangements and other specific conditions to be treated) distinction, for example, the mathematical basis for the relatively weak class, should explain the characteristics of the model based on their professional and educational programs have selectively and focus on explaining the basic concepts and basic principle) and the mathematical basis for a better class, taught in the basic concepts and principles, based on the emphasis on cultivating their logical thinking ability to understand mathematical model assumptions, argumentation and economic implications and so on.

\section{Acknowledgements}

Proj: Hubei Institute of Science and Technology, Teaching and Research Project. Project No. 2014-xc-023

\section{REFERENCE:}

[1] Cao Huiping .Teaching Reform on International Economic and Trade Research [J]. Modern Enterprise Education, 2008 (14).

[2] Jiang Xinhai. Reflections on Chinese Universities \& International Economics Course [J]. Guangdong University of Technology, 2007 (6).

[3] Huang Hua. Case Teaching in The Application of International Economics Course [J]. Inner Mongolia Finance and Economics College, 2008 (6).

[4] Zhou Rong. International Economics Curriculum Reform Reflections [J]. Law and Society, 2005 (10).

[5] Zhang Hui. International Economics Course Construction Problems [J]. Business Economics, 2009 (12). 